\title{
Estimating of gross primary production in an Amazon-Cerrado transitional forest using MODIS and Landsat imagery
}

\author{
VICTOR H.M. DANELICHEN ${ }^{1}$, MARCELO S. BIUDES ${ }^{1}$, \\ MAÍSA C.S. VELASQUE ${ }^{1}$, NADJA G. MACHADO ${ }^{1,2}$, RAPHAEL S.R. GOMES ${ }^{1}$, \\ GEORGE L. VOURLITIS ${ }^{3}$ and JOSÉ S. NOGUEIRA ${ }^{1}$ \\ ${ }^{1}$ Programa de Pós-Graduação em Física Ambiental, \\ Instituto de Física, Universidade Federal de Mato Grosso, \\ Av. Fernando Corrêa da Costa, 2367, 78060-900 Cuiabá, MT, Brasil \\ ${ }^{2}$ Laboratório da Biologia da Conservação, Instituto Federal de Mato Grosso, Campus \\ Cuiabá, Bela Vista, Av. Juliano Costa Marques, s/n, 78050-560 Cuiabá, MT, Brasil \\ ${ }^{3}$ Biological Sciences Department, California State University, San Marcos, 333 S. \\ Twin Oaks Valley Rd., Zip Code 92096, San Marcos, California, USA
}

Manuscript received on September 9, 2014; accepted for publication on December 5, 2014

\begin{abstract}
The acceleration of the anthropogenic activity has increased the atmospheric carbon concentration, which causes changes in regional climate. The Gross Primary Production (GPP) is an important variable in the global carbon cycle studies, since it defines the atmospheric carbon extraction rate from terrestrial ecosystems. The objective of this study was to estimate the GPP of the Amazon-Cerrado Transitional Forest by the Vegetation Photosynthesis Model (VPM) using local meteorological data and remote sensing data from MODIS and Landsat 5 TM reflectance from 2005 to 2008. The GPP was estimated using Normalized Difference Vegetation Index (NDVI) and Enhanced Vegetation Index (EVI) calculated by MODIS and Landsat 5 TM images. The GPP estimates were compared with measurements in a flux tower by eddy covariance. The GPP measured in the tower was consistent with higher values during the wet season and there was a trend to increase from 2005 to 2008 . The GPP estimated by VPM showed the same increasing trend observed in measured GPP and had high correlation and Willmott's coefficient and low error metrics in comparison to measured GPP. These results indicated high potential of the Landsat 5 TM images to estimate the GPP of Amazon-Cerrado Transitional Forest by VPM.
\end{abstract}

Key words: Amazon Basin, Cerrado, carbon cycle, climate change, deforestation, ecosystem function.

\section{INTRODUCTION}

The study of net exchange of carbon dioxide in the ecosystem (NEE) and gross primary production (GPP) provide important information about the environment, since the GPP defines the rate at which an ecosystem accumulate biomass (Xiao et al. 2004). The understanding of the spatial-temporal variation in GPP is critical for assessing the carbon cycles and improving regional and global climate models. The GPP values

Correspondence to: Marcelo Sacardi Biudes

E-mail:marcelo@fisica.ufmt.br 
are dependent of the interaction between biogeochemical cycling, plant physiology, soil water availability, and climate (Fisher et al. 2007, da Rocha et al. 2009, Costa et al. 2010).

Atmospheric composition and some of its constituents are changing due to anthropogenic activity. The average $\mathrm{CO}_{2}$ concentration increased from $280 \mathrm{ppm}$ in the XIX century to $398.8 \mathrm{ppm}$ in August 2014 (NOAA 2014). This increase is mainly attributed to human activity, through industrialization, burning fossil fuels, land use change, agriculture and livestock (IPCC 2014). By 2012, some 749,987 $\mathrm{km}^{2}$ of forest, or about $20 \%$ of the original forest extent of the Brazilian Legal Amazon, had been cleared (INPE 2013, Godar et al. 2014). Large areas of the remaining forests have been severely degraded and fragmented by logging, fire, and overhunting (Davidson et al. 2012). This represents a decrease in the amount of carbon, climate change in the region and changes in ecosystem functioning (Vourlitis et al. 2011).

In Mato Grosso, deforestation practices for livestock and agricultural activity as the cultivation of soybeans, corn and cotton has been intensified (Fearnside 2001). Between 2009 and 2011, 70\% of whole Brazil deforestation occurred in the Mato Grosso and Pará States (Fearnside et al. 2012). In the north of Mato Grosso there is a transitional forest between the Amazon and the Cerrado (Vourlitis et al. 2011). The mix of two distinct vegetation defines this region, which has its own characteristics (Ackerly et al. 1989). The forest of this transition region is more sensitive to climate change (Malhi and Wright 2004). Some research shows that over the past 30 years, the region had higher temperatures than the Central Amazon Basin (Vourlitis et al. 2011, Souza et al. 2014, Biudes et al. 2014b) and accelerated deforestation associated with changes possibly climate is affecting gas exchange in this region.

The measurement of GPP is usually made in micrometeorological stations using eddy covariance method (Vourlitis et al. 2011, Souza et al. 2014, Biudes et al. 2014b). However, this technique provides point values, which is not always characterized the spatial variability in regional scale. Furthermore, the Eddy Covariance technique in some cases is not viable due to high cost or poor homogeneity of the sampled site (Souza et al. 2014). Remote sensing techniques are advantageous because they allow monitoring the GPP on a regional scale, providing a better understanding of the effects of land use change (Courault et al. 2005, Allen et al. 2011).

The Vegetation Photosynthesis Model (VPM), proposed by Xiao et al. (2004), is a model based on the vegetation light use efficiency, air temperature and photosynthetic active radiation (PAR) and satellite data (Xiao et al. 2004). The VPM has been used to estimate the GPP in several vegetation cover as temperate deciduous broadleaf forest (Xiao et al. 2004, Wu et al. 2010), seasonally moist tropical forest (Xiao et al. 2005), semi-deciduous tropical forest (Souza et al. 2014, Biudes et al. 2014b), and croplands (Li et al. 2007, Wang et al. 2010), using Moderate Resolution Imaging Spectroradiometer (MODIS) reflectance. The MODIS has the advantage of high temporal resolution (cover the entire earth every 1 to 2 days), because of the two different platforms (TERRA and AQUA). The spatial resolution of MODIS varies with the band: $250 \mathrm{~m}$ form bands 1 and 2, $500 \mathrm{~m}$ for bands 3-7 and $1000 \mathrm{~m}$ for bands 8-36, which includes the thermal bands. The Landsat $5 \mathrm{TM}$ has the advantage of high spatial resolution $(30 \mathrm{~m})$, but lower temporal resolution (16 days). However, few studies about the GPP estimates from Landsat 5 TM had been performance (Bastiaanssen and Ali 2003, Silva et al. 2013).

Given the need for further clarification of the potential of Landsat 5 TM to estimate the regional GPP, the objective of this study was to estimate the GPP of the Amazon-Cerrado Transitional Forest by the VPM using local meteorological data and remote sensing data from MODIS and Landsat 5 TM reflectance. 


\section{MATERIALS AND METHODS}

\section{SITE DESCRIPTIONS}

The study was conducted in a dense, semi-deciduous forest located in the Amazon-Cerrado transition zone

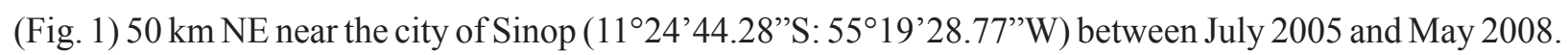
The 30-year mean annual temperature in the Sinop area is $24^{\circ} \mathrm{C}$ with little seasonal variation, and rainfall is approximately $2000 \mathrm{~mm}_{\text {year }}^{-1}$ (Vourlitis et al. 2008) with a 4-5 month dry season (May-September). Mean canopy height is $22-25 \mathrm{~m}$, and leaf area index (LAI) varies between 6-7 $\mathrm{m}^{2} \mathrm{~m}^{-2}$ during the dry season and 7-8 $\mathrm{m}^{2} \mathrm{~m}^{-2}$ during the wet season (Biudes et al. 2014a), and the vegetation is dominated by tree species such as Brosimum lactescens, Qualea paraensis and Tovomita schomburkii (Vourlitis et al. 2015). The soil is a Quartzarenic Neosol characterized by sandy texture (84\% sand, 4\% silt, and $12 \%$ clay in the upper 50 $\mathrm{cm}$ of soil), poor nutrients, high porosity, and drain rapidly after rainfall events (Priante-Filho et al. 2004).

Micrometeorological MEASUREMENTS

A micrometeorological tower was installed in the experimental area and continuously collected data on photosyntheticaly active radiation (LI-190SB, LI-COR, Lincoln, NE, USA), and air temperature and

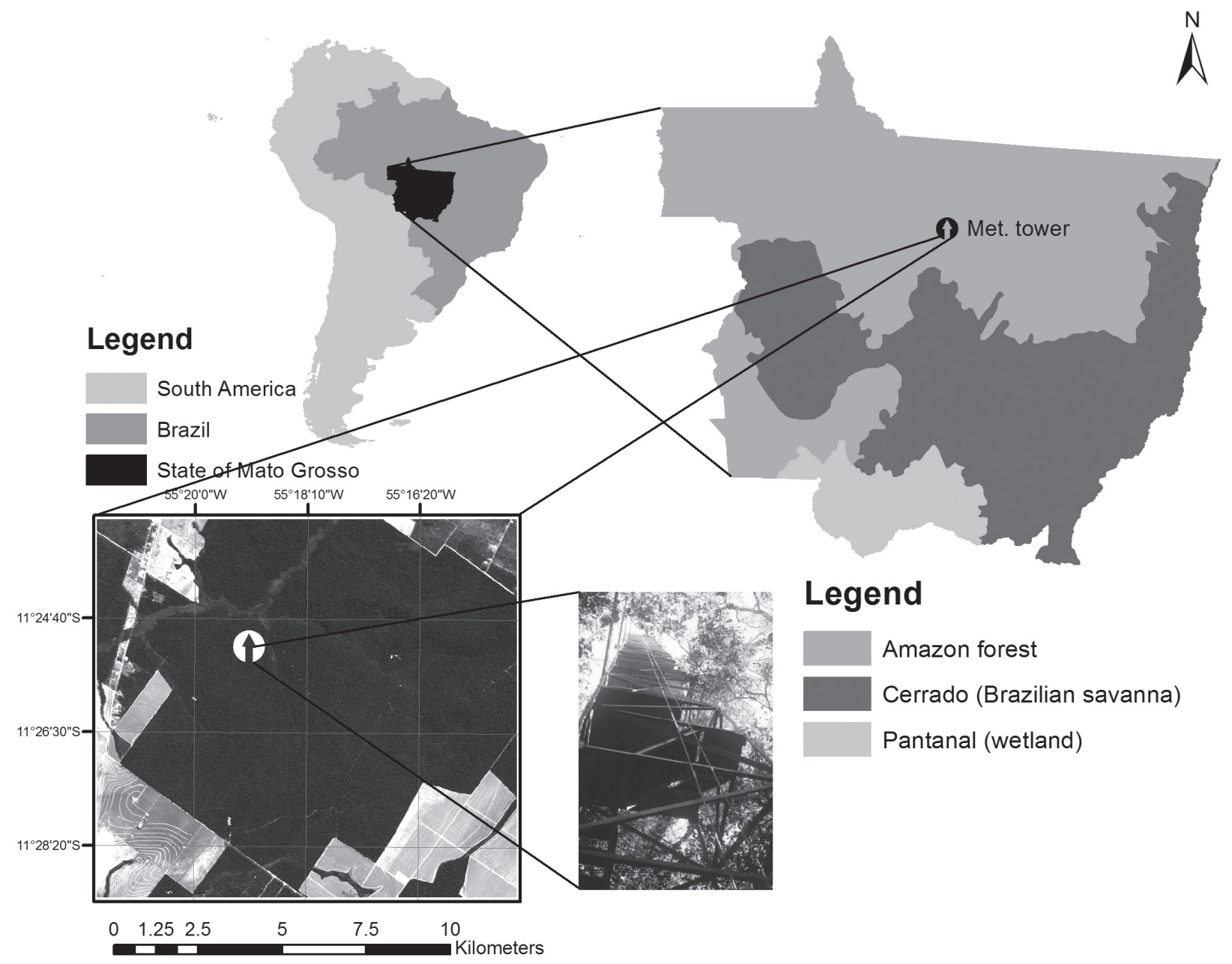

Fig. 1 - Location of the micrometeorological tower in in the Amazon-Cerrado transitional forest. 
relative humidity (HMP-45 C, Vaisala, Inc., Helsinki, Finland) at $40 \mathrm{~m}$ height. The 3-dimension wind speed was measured by a sonic anemometer (CSAT-3, Campbell Scientific, Inc., Logan, UT, USA), and the $\mathrm{CO}_{2}$ concentration by an open path infrared gas analyzer (LI-7500, LI-COR, Inc. Lincoln, NE, USA) at $42 \mathrm{~m}$ height. The data signals produced by the transducers were processed and stored every 30 minutes by a datalogger (CR5000, Campbell Scientific, Inc., Logan, UT, USA). Precipitation was obtained daily in Farm Maracaí through a manual rain collector located $5 \mathrm{~km}$ southwest of micrometeorological tower.

\section{REMOTE SENSING MEASUREMENTS}

\section{Vegetation Indexes by MODIS data}

The Moderate Resolution Imaging Spectroradiometer (MODIS) sensor is composed of images of 36 spectral bands ranging from 0.4 to $14.4 \mu \mathrm{m}$. Seven of their 36 bands are designed for the study of vegetation and land surface: blue (459-479 nm) - 3 band, green (545-565 nm) - 4 band, red (620-670 $\mathrm{nm})$ - band 1, near infrared NIR (841-875 nm, 1230-1250 nm) band - 2:05, and far infrared SWIR (1628-1652 nm, 2105-2155 nm) band -6 and 7. The MODIS data sets are available from 8 to 8 days, corrected for the effects of atmospheric gases, aerosols, and thin cirrus clouds. These time series data are published by the Center for EROS Data Center Active Archive (EDC Daac), and for this study we used the average of nine pixels that partially cover the tower, and these were used only the pixels with the highest indicators warranty quality. To improve the signal to noise MODIS a reconstruction of the filtered data relation were performed using the Singular Spectrum Analysis by the catMV software (Golyandina and Osipova 2007).

The land surface reflectance product (MOD09A1) includes seven spectral bands with a spatial resolution of $500 \mathrm{~m}$. The Normalized Difference Vegetation Index (NDVI - Eq. 1), Enhanced Vegetation Index (EVI - Eq. 2) and Land Surface Water Index (LSWI - Eq. 3) were calculated using the blue band $\left(\rho_{\text {blue }}\right)$, red band $\left(\rho_{\text {red }}\right)$, near infrared band $\left(\rho_{\text {nir }}\right)$ and shortwave infrared $\left(\rho_{\text {swir }}\right)$ (Huete et al. 1997, Xiao et al. 2004).

$$
\begin{gathered}
N D V I=\frac{\rho_{\text {nir }}-\rho_{\text {red }}}{\rho_{\text {nir }}+\rho_{\text {red }}} \\
E V I=2.5 \frac{\rho_{\text {nir }}-\rho_{\text {red }}}{\rho_{\text {nir }}+6 \rho_{\text {blue }}-7.5 \rho_{\text {red }}+1} \\
L S W I=2.5 \frac{\rho_{\text {nir }}-\rho_{\text {swir }}}{\rho_{\text {nir }}+\rho_{\text {swir }}}
\end{gathered}
$$

\section{Vegetation indexes by Landsat 5 TM}

The reflectance generated by the Thematic Mapper - Landsat 5 TM for Patch 226 and Row 68 on dates of the Table I were obtained from the database of the Earth Explorer US Geological Survey - USGS [http:// earthexplorer.usgs.gov/]. The reflectance downloaded from the USGS was composed of seven spectral bands with spatial resolution of $30 \times 30 \mathrm{~m}$. The reflectance of the surface is generated from specialized software Landsat Ecosystem Disturbance Adaptive Processing System (LEDAPS), which was developed by the National Aeronautics and Space Administration (NASA) in which performs LEPADS atmospheric corrections for each band imaging (http://daac.ornl.gov/MODELS/guides/LEDAPS.html). The pixels with low quality assurance (QA) metrics were not considered. 
TABLE I

Date, day of the year (DOY), UTM time, local time, square of the earth-sun distance (dr), solar elevation angle $(E)$ of the Landsat 5 TM images and the air temperature $\left(\mathrm{T}-{ }^{\circ} \mathrm{C}\right)$ and relatively humidity (RH - \%) and photosynthetic active radiation (PAR $-\mathrm{W} \mathrm{m}^{-2}$ ) during the Landsat $5 \mathrm{TM}$ overpass in the Amazon-Cerrado transitional forest from July 2005 to June 2008.

\begin{tabular}{ccccccccc}
\hline Date & DOY & UTM Time & Local Time & dr & E & T & RH & PAR \\
\hline $10 / 07 / 2005$ & 191 & $13: 32: 06$ & $09: 32: 06$ & 0.9674 & 43.56 & 24.7 & 60.9 & 483.4 \\
$26 / 07 / 2005$ & 207 & $13: 32: 17$ & $09: 32: 17$ & 0.9699 & 45.23 & 24.6 & 58.2 & 503.9 \\
$27 / 08 / 2005$ & 239 & $13: 32: 31$ & $09: 32: 31$ & 0.9814 & 51.93 & 26.6 & 64.9 & 377.8 \\
$28 / 09 / 2005$ & 271 & $13: 32: 32$ & $09: 32: 32$ & 0.9984 & 59.89 & 27.6 & 65.9 & 494.2 \\
$26 / 05 / 2006$ & 146 & $13: 36: 40$ & $09: 36: 40$ & 0.9733 & 46.53 & 24.4 & 70.1 & 391.7 \\
$27 / 06 / 2006$ & 178 & $13: 37: 12$ & $09: 37: 12$ & 0.9671 & 44.01 & 23.4 & 65.8 & 527.6 \\
$29 / 07 / 2006$ & 210 & $13: 37: 37$ & $09: 37: 37$ & 0.9706 & 46.62 & 25.1 & 65.6 & 557.2 \\
$14 / 08 / 2006$ & 226 & $13: 37: 49$ & $09: 37: 49$ & 0.9758 & 49.80 & 25.3 & 50.2 & 567.7 \\
$30 / 08 / 2006$ & 242 & $13: 38: 01$ & $09: 38: 01$ & 0.9828 & 53.81 & 25.8 & 59.5 & 511.0 \\
$15 / 09 / 2006$ & 258 & $13: 38: 14$ & $09: 38: 14$ & 0.9912 & 58.09 & 26.9 & 63.3 & 452.4 \\
$18 / 11 / 2006$ & 322 & $13: 38: 53$ & $09: 38: 53$ & 1.0244 & 60.07 & 27.0 & 63.4 & 718.0 \\
$20 / 12 / 2006$ & 354 & $13: 39: 08$ & $09: 39: 08$ & 1.0324 & 60.12 & 24.3 & 70.1 & 471.2 \\
$10 / 03 / 2007$ & 69 & $13: 39: 22$ & $09: 39: 22$ & 1.0123 & 57.46 & 24.7 & 69.7 & 373.7 \\
$26 / 03 / 2007$ & 85 & $13: 39: 20$ & $09: 39: 20$ & 1.0035 & 56.41 & 26.1 & 70.3 & 403.2 \\
$13 / 05 / 2007$ & 133 & $13: 38: 59$ & $09: 38: 59$ & 0.9783 & 48.96 & 24.6 & 63.4 & 445.0 \\
$14 / 06 / 2007$ & 165 & $13: 38: 28$ & $09: 38: 28$ & 0.9685 & 44.74 & 26.0 & 63.6 & 546.8 \\
$30 / 06 / 2007$ & 181 & $13: 38: 11$ & $09: 38: 11$ & 0.9670 & 44.21 & 23.7 & 61.9 & 532.4 \\
$16 / 07 / 2007$ & 197 & $13: 38: 04$ & $09: 38: 04$ & 0.9680 & 45.02 & 23.6 & 58.1 & 505.5 \\
$01 / 08 / 2007$ & 213 & $13: 37: 56$ & $09: 37: 56$ & 0.9714 & 47.18 & 23.3 & 49.2 & 525.1 \\
$17 / 08 / 2007$ & 229 & $13: 37: 45$ & $09: 37: 45$ & 0.9770 & 50.47 & 22.8 & 37.6 & 628.7 \\
$02 / 09 / 2007$ & 245 & $13: 37: 37$ & $09: 37: 37$ & 0.9843 & 54.51 & 25.2 & 57.6 & 466.0 \\
$18 / 09 / 2007$ & 261 & $13: 37: 29$ & $09: 37: 29$ & 0.9928 & 58.67 & 25.1 & 73.6 & 351.4 \\
\hline
\end{tabular}

The Landsat 5 TM Normalized Difference Vegetation Index (NDVI) was calculated by the Eq. (4).

$$
N D V I=\frac{\rho_{\lambda 4}-\rho_{\lambda 3}}{\rho_{\lambda 3}+\rho_{\lambda 4}}
$$

where $\rho_{\lambda 3}$ and $\rho_{\lambda 4}$ are the band 3 and 4 from Landsat $5 \mathrm{TM}$, respectively.

The equation of Landsat 5 TM Enhanced Vegetation Index (EVI) determined empirically by Jensen (2009) contains an adjustment factor for soil (L) and two coefficients (C1 and C2), assuming 1.0, 6.0 and 7.5 as their values. The equation adjusted by Jensen (2009) was determined to non-atmospheric corrected Landsat 5 TM images. Therefore, the blue band in the Jensen (2009) EVI equation is used to correct the red band and the atmospheric scattering (Jensen 2009). Since we obtained atmospheric corrected Landsat 5 TM images from USGS website, we decide to use the equation proposed by Jiang et al. (2008) (Eq. 5), which features similar to traditional EVI index and has better sensitivity in areas with high biomass. Besides, the EVI proposed by Jiang et al. (2008) do not use the blue band (band 1), which presents distortions resulting from atmospheric scattering (Jiang et al. 2008).

$$
E V I=2.5 \times \frac{\rho_{\lambda 4}-\rho_{\lambda 3}}{\left(\rho_{\lambda 4}+2.4 \times \rho_{\lambda 3}+1\right)}
$$


The Landsat 5 TM Land Surface Water Index (LSWI) was calculated by Eq. (6).

$$
L S W I=\frac{\rho_{\lambda 4}-\rho_{\lambda 5}}{\rho_{\lambda 4}+\rho_{\lambda 5}}
$$

where $\rho_{\lambda 4}$ and $\rho_{\lambda 5}$ are the band 4 and 5 from Landsat 5 TM, respectively.

\section{MODIS 8-day Gross Primary Production product (GPP $\left.P_{M O D I S}\right)$}

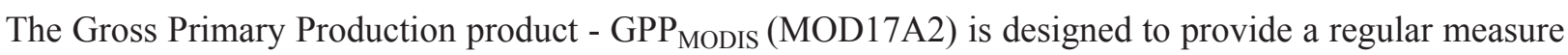
of the growth of terrestrial vegetation based on the light use efficiency concept (LUE), and using daily MODIS land cover, FPAR/LAI. The product is computed using the Eq. (7).

$$
G P P=\varepsilon_{\text {max }} \cdot m\left(T_{\text {min }}\right) \cdot m(V P D) \cdot F P A R \cdot S W_{\text {rad }} \cdot 0.45
$$

where $\varepsilon_{\max }$ is the maximum LUE obtained from the lookup table based on the type of vegetation, $m\left(T_{\min }\right)$ and $m(V P D)$ are scales to reduce $\varepsilon_{\text {max }}$ under unfavorable conditions of low temperature and high deficit vapor pressure, FPAR is the fraction of photosynthetic active radiation absorbed by vegetation and $S W_{\text {rad }}$ is the shortwave radiation.

Gross Primary Production Measured by Eddy Covariance Method (GPP ec $_{\text {) }}$

The eddy covariance method is more appropriate for the study of physical phenomena in forests because the carbon exchange occurs turbulently (da Rocha 2009, Vourlitis et al. 2011). The infrared gas analyzer was installed downwind of approximately $5 \mathrm{~cm}$ of sonic anemometer to minimize the effect of the separation of sensors and an inclination of $20^{\circ}$ to prevent accumulation of water. The sensors were oriented in the prevailing wind direction to minimize distortions. The predominant wind direction was southwest and southeast. The average $\mathrm{CO}_{2}$ flux was calculated by the covariance of vertical wind speed fluctuations and $\mathrm{CO}_{2}$ concentration. The $\mathrm{CO}_{2}$ flux was estimated and corrected by the simultaneous oscillation of heat (Webb et al. 1980). Every hour the net ecosystem exchange (NEE) was calculated as the sum of $\mathrm{CO}_{2}$ flow and the carbon storage in the canopy. The carbon storage in the canopy was determined by quantifying the rate of variation of this carbon dioxide in the air column between the ground surface and the sensors (Vourlitis et al. 2011). Samples were taken at 1, 4, 12, 20 and $28 \mathrm{~m}$ above the ground level using a diaphragm pump and the solenoid switching system, and the profile vertical $\mathrm{CO}_{2}$ concentration. Gross Primary Production measured by eddy covariance $\left(\mathrm{GPP}_{\mathrm{EC}}-\mathrm{gC} \mathrm{m}^{-2} \mathrm{day}^{-1}\right)$ was calculated by Eq. (8).

$$
G P P=N E E+R
$$

where $N E E$ is the net ecosystem exchange $\left(\mathrm{gC} \mathrm{m}^{-2} \mathrm{day}^{-1}\right)$ and $R$ is the ecosystem respiration $\left(\mathrm{gC} \mathrm{m}^{-2}\right.$ day $\left.^{-1}\right)$ (Wohlfahrt et al. 2005). The GPP and $R$ were estimated every half hour and integrated for each day. The $R$ for every half hour was estimated as the average of NEE during the first four hours of the day $(0-4 \mathrm{~h})$, assuming zero $\mathrm{CO}_{2}$ assimilation during this period. After obtaining the value of $\mathrm{R}$, the GPP was estimated as the sum of R and NEE every half hour (Vourlitis et al. 2011, Souza et al. 2014).

\section{GPP Estimated by Vegetation Photosynthesis Model (VPM)}

The GPP estimated by the Vegetation Photosynthesis Model (VPM) (Eq. 9) is a function of photosynthetic active radiation PAR ( $\left.\mathrm{mol} \mathrm{m}^{-2} \mathrm{~s}^{-1}\right)$, light use efficiency $\varepsilon_{g}\left(\mathrm{gC} \mathrm{molPAR}^{-1}\right)$ and the fraction of absorbed PAR by chlorophyll in the vegetation canopy $\left(F P A R_{c h l}\right)$ (Xiao et al. 2004). 


$$
G P P=\varepsilon_{g} \cdot F P A R_{c h l} \cdot P A R
$$

The FPAR and consequently GPP were calculated using the EVI $\left(F P A R_{E V I}\right)$ and NDVI $\left(F P A R_{N D V I}\right)$ calculated from Landsat $5 \mathrm{TM}$ and MODIS reflectance. The $F P A R_{E V I}$ (Eq. 10) was calculated as linear function of EVI and the coefficient $\alpha$ was set to 1.0 (Xiao et al. 2004, 2005, Wang et al. 2010), and the $F_{P A R_{N D V I}}$ was calculated by Eq. (11) as a linear relation with NDVI (Hatfield et al. 1984, Asrar et al. 1992)

$$
\begin{gathered}
F_{P A R_{E V I}}=\alpha \cdot E V I \\
F_{P A R_{N D V I}}=-0.168+1.24 \times N D V I
\end{gathered}
$$

The light use efficiency $\varepsilon_{g}$ is difficult to determine on a global scale (Wu et al. 2010), and varies from spatially and temporal and depends on factors such as temperature and soil water content. The $\varepsilon_{g}$ was calculated by Eq. (12).

$$
\varepsilon_{g}=\varepsilon_{0} \cdot T_{e s c} \cdot W_{e s c} \cdot P_{e s c}
$$

where $\varepsilon_{0}$ is the maximum light use efficiency $\left(\mathrm{gC} \mathrm{molPAR}^{-1}\right)$ and $T_{\text {esc }}$ (Eq. 13), and $W_{\text {esc }}$ (Eq. 14) and $P_{\text {esc }}$ (Eq. 15) are scalars regulator, ranging between 0 and 1 for the effects of temperature, soil water content water, and foliage phenology.

$$
\begin{gathered}
T_{\text {esc }}=\frac{\left(T-T_{\min }\right)\left(T-T_{\max }\right)}{\left[\left(T-T_{\min }\right)\left(T-T_{\max }\right)\right]-\left(T-T_{\text {opt }}\right)^{2}} \\
W_{\text {esc }}=\frac{1+L S W I}{1+L S W I_{\max }} \\
P_{\text {esc }}=\frac{1+L S W I}{2}
\end{gathered}
$$

where $T, T_{\min }, T_{\max }$ and $T_{\text {opt }}$ are the daily average air temperature and the minimum, maximum and optimum air temperature to the photosynthetic activity, which we set to $2^{\circ} \mathrm{C}, 40^{\circ} \mathrm{C}$ e $35.1^{\circ} \mathrm{C}$ (Souza et al. 2014), respectively. If the air temperature is lower than $T_{\min }$ and higher than $T_{\max }, T_{\text {esc }}$ is zero. $L S W I$ is the MODIS and Landsat 5 TM Lands Surface Water Index and $L S W I_{\max }$ is the maximum $L S W I$ during the vegetation grown period.

Semi-deciduous trees in the tropical zone have a green cover throughout the year, because the foliage is retained for several growing seasons. Cups of semi-deciduous forests are therefore composed of green leaves of various ages. For this study, we admit the assumption $P_{\text {esc }}$ set to 1 , similar to that used for the evergreen broadleaf forest (Xiao et al. 2005). The $\varepsilon_{0}$ was estimated using a non-linear hyperbolic function proposed to Michaelis-Menten (Eq. 16).

$$
N E E=\frac{\varepsilon_{0} \cdot P A R \cdot G P P_{\max }}{\varepsilon_{0} \cdot P A R+G P P_{\max }}-R_{e}
$$

where NEE is daily net ecosystem exchange measured by eddy covariance $\left(\mathrm{gC} \mathrm{m}^{-2}\right.$ day $\left.^{-1}\right)$, PAR is the photosynthetic active radiation $\left(\mathrm{mol} \mathrm{m}^{-2}\right.$ day $\left.^{-1}\right)$ measured in the flux tower, $G P P_{\max }$ is the maximum daily GPP measured in the flux tower by eddy covariance $\left(\mathrm{gC} \mathrm{m}^{-2}\right.$ day $\left.{ }^{-1}\right)$ and $R_{e}$ is the daily ecosystem respiration measured by eddy covariance $\left(\mathrm{gC} \mathrm{m}^{-2} \mathrm{day}^{-1}\right)$. The $\varepsilon_{0}$ was estimated monthly according to Souza et al. 2014 .

STATISTICAL ANALYSIS

EVI, NDVI and LSWI values calculated from MODIS reflectance were averaged for the nine pixels covering and surrounding the flux tower, and only pixels with highest quality assurance (QA) metrics were used. 
Varying sensor viewing geometry, cloud presence, aerosols and bidirectional reflectance can limit the efficacy of reflectance data for assessing spatial-temporal dynamics in biophysical processes (Hird and McDermid 2009), and signal extraction techniques are often needed to improve the signal-noise ratio (Hermance et al. 2007). Thus, we applied Singular Spectrum Analysis (SSA) using the CatMV software (Golyandina and Osipova 2007), which has been shown to be effective for the filtered reconstruction of short, irregularly spaced, and noisy time series and improving the signal-noise ratio of the MODIS EVI, NDVI and LSWI (Ghil et al. 2002).

Willmott's index "d" (Eq. 17), the root mean square error "RMSE" (Eq. 18), the mean absolute error "MAE" (Eq. 19) and the Pearson correlation were used to evaluate the performance of the GPP estimated by VPM using EVI and NDVI from MODIS and Landsat 5 TM and the MOD17A2 GPP MODIS Product.

$$
\begin{gathered}
d=1-\left[\frac{\sum\left(P_{i}-O_{i}\right)^{2}}{\sum\left(\left|P_{i}-O\right|+\left|O_{i}-O\right|\right)^{2}}\right] \\
R M S E=\sqrt{\frac{\sum\left(P_{i}-O_{i}\right)^{2}}{n}} \\
M A E=\sum \frac{\left|P_{i}-O_{i}\right|}{n}
\end{gathered}
$$

where $P_{i}$ is the estimated value, $O_{i}$ the value observed, $O$ the average of observed values and $n$ is the number of observations. Willmott's statistic relates the performance of an estimation procedure based on the distance between estimated and observed values, with values ranging from zero (no agreement) to 1 (perfect agreement). The RMSE indicates how the model fails to estimate the variability in the measurements around the mean and measures the change in the estimated values around the measured values (Willmott and Matssura 2005). The lowest threshold of RMSE is 0 , which means there is complete agreement between the model estimates and measurements. The $M A E$ indicates the distance (deviation) mean absolute values estimated from the values measured. Ideally, the values of the $M A E$, and the RMSE were close to zero (Willmott and Matssura 2005).

\section{RESULTS AND DISCUSSION}

\section{INTERANNUAL AND SEASONAL PATTERns OF MiCROMETEOROLOGICAL AND VEGETATION INDEXES DATA}

Weather conditions varied considerably throughout the experiment and all three annual period had different pattern: wet and hot during 2006-07, dry and cool during 2007-08 and dry and hot during 2005-06 (Vourlitis et al. 2011). The interannual rainfall ranged between 1498.5 and $2100.6 \mathrm{~mm}$, with an average of $1754.1 \mathrm{~mm}$ (Table II). The highest annual precipitation occurred during 2006-07 with a maximum in January 2007 $(558 \mathrm{~mm})$, and there were several months with no precipitation during the dry season (Fig. 2a).

The photosynthetic active radiation (PAR) had higher annual average in 2006-07 and the higher seasonal average PAR occur during the dry season of 2005-06 and the lowest during the rainy season of years 200708 (Table II; Fig. 2b). The highest values of PAR in the dry season are associated with lower cloudiness in this season (da Rocha et al. 2009). The air temperature had higher values in 2005-06 and varied seasonality during all years (Table II). The maximum air temperature values occurred in September and minimum in July 


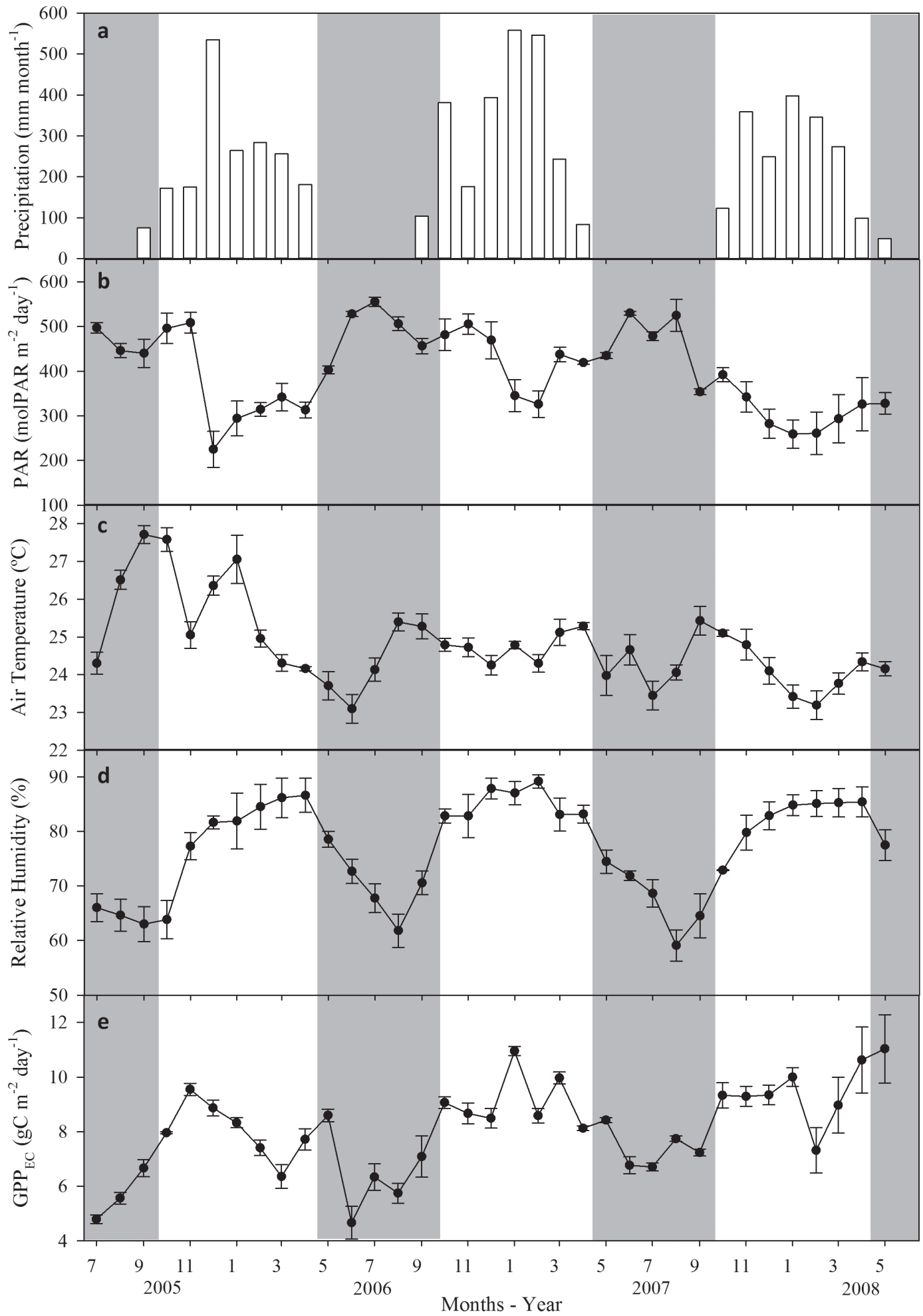

Fig. 2 - Monthly precipitation (a), monthly average ( \pm standard deviation) of photosynthetic active radiation (PAR) (b), air temperature (c), relative humidity (d) and gross primary production measured by the eddy covariance $\left(\mathrm{GPP}_{\mathrm{EC}}\right)(\mathbf{e})$ in the Amazon-Cerrado transitional forest from July 2005 to June 2008. The gray vertical column represents the dry season. 
TABLE II

Annual and seasonal accumulated precipitation (Ppt - mm), mean ( \pm standard deviation) of Photosynthetic Active Radiation (PAR - molPAR day $^{-1}$ ), air temperature (Air temp - ${ }^{\circ} \mathrm{C}$ ), relative humidity (RH -\%), Gross Primary Production measured by eddy covariance $\left(\mathrm{GPP}_{\mathrm{EC}}-\mathrm{gC} \mathrm{m}^{-2} \mathrm{day}^{-1}\right)$, Enhanced Vegetation

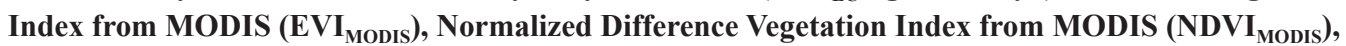

Enhanced Vegetation Index from Landsat 5 TM $\left(\mathrm{EVI}_{\text {Landsat }}\right)$, Normalized Difference Vegetation Index from Landsat 5 TM (NDVI ${ }_{\text {Landsat }}$ ) in the Amazon-Cerrado transitional forest from July 2005 to June 2008.

\begin{tabular}{cccc|ccc|ccc}
\hline & \multicolumn{3}{c|}{ Anual } & \multicolumn{3}{c|}{ Dry } & \multicolumn{3}{c}{ Wet } \\
\hline & $\mathbf{2 0 0 5 - 0 6}$ & $\mathbf{2 0 0 6 - 0 7}$ & $\mathbf{2 0 0 7 - 0 8}$ & $\mathbf{2 0 0 5 - 0 6}$ & $\mathbf{2 0 0 6 - 0 7}$ & $\mathbf{2 0 0 7 - 0 8}$ & $\mathbf{2 0 0 5 - 0 6}$ & $\mathbf{2 0 0 6 - 0 7}$ & $\mathbf{2 0 0 7 - 0 8}$ \\
\hline Ppt & 1498.5 & 2100.6 & 1663.1 & 89.5 & 104.0 & 49.0 & 1409.0 & 2048.6 & 1638.6 \\
PAR & $400.6 \pm 22.8$ & $455.5 \pm 19.0$ & $354.8 \pm 22.8$ & $479.0 \pm 13.2$ & $477.0 \pm 11.0$ & $441.6 \pm 14.4$ & $395.0 \pm 30.0$ & $376.0 \pm 24.1$ & $339.0 \pm 23.8$ \\
Air Temp. & $25.4 \pm 0.30$ & $24.7 \pm 0.2$ & $24.2 \pm 0.2$ & $25.0 \pm 0.2$ & $24.3 \pm 0.3$ & $24.2 \pm 0.3$ & $25.3 \pm 0.2$ & $24.8 \pm 0.2$ & $24.4 \pm 0.2$ \\
RH & $75.5 \pm 7.7$ & $78.5 \pm 4.2$ & $75.0 \pm 1.9$ & $68.1 \pm 9.2$ & $68.9 \pm 6.2$ & $69.3 \pm 2.5$ & $81.5 \pm 5.9$ & $83.6 \pm 4.5$ & $83.1 \pm 1.6$ \\
$\mathrm{GPP}_{\text {ec }}$ & $7.2 \pm 0.2$ & $8.1 \pm 0.2$ & $8.8 \pm 0.2$ & $6.1 \pm 0.3$ & $6.9 \pm 0.2$ & $7.9 \pm 0.1$ & $8.2 \pm 0.2$ & $8.6 \pm 0.2$ & $9.3 \pm 0.3$ \\
EVI $_{\text {MODIS }}$ & $0.59 \pm 0.01$ & $0.58 \pm 0.01$ & $0.59 \pm 0.01$ & $0.58 \pm 0.01$ & $0.57 \pm 0.01$ & $0.56 \pm 0.01$ & $0.60 \pm 0.01$ & $0.60 \pm 0.01$ & $0.60 \pm 0.01$ \\
NDVI $_{\text {MODIS }}$ & $0.86 \pm 0.00$ & $0.86 \pm 0.00$ & $0.87 \pm 0.00$ & $0.86 \pm 0.00$ & $0.86 \pm 0.00$ & $0.87 \pm 0.00$ & $0.86 \pm 0.00$ & $0.87 \pm 0.00$ & $0.87 \pm 0.00$ \\
EVI $_{\text {Landsat }}$ & --- & --- & --- & $0.47 \pm 0.01$ & $0.48 \pm 0.01$ & $0.48 \pm 0.01$ & --- & $0.57 \pm$ & --- \\
NDVI $_{\text {Landsat }}$ & --- & --- & --- & $0.81 \pm 0.04$ & $0.82 \pm 0.03$ & $0.81 \pm 0.02$ & --- & $0.85 \pm 0.01$ & --- \\
\hline
\end{tabular}

(Fig. 2c) during the dry season (Table II), when the cold fronts advance from the south to the Amazon Basin (Machado et al. 2004). The relative humidity varied interannualy and seasonally with maximum values during wet season (Table II), and positively correlated with precipitation ( $\mathrm{r}=0.72$; $\mathrm{p}$-value $<0.0001)$. The maximum relative humidity values occurred in February 2007 and minimum in August 2007 (Fig. 2d).

The GPP measured by eddy covariance $\left(\mathrm{GPP}_{\mathrm{EC}}\right)$ had higher values during 2007-08, 9\% higher than 2005-06, which showed a trend to increase during the study period (Table II). The GPP $\mathrm{EC}_{\text {varied seasonally }}$ with values $17 \%$ higher during the rainy season (Table II), with gradual increase from July to November and peaks in November and January (Fig. 2e).

Seasonal variations of EVI and NDVI calculated with MODIS and Landsat 5 TM reflectance were consistent along of the years, with lower values during the dry season (May to September) and higher during the rainy season. EVI and NDVI increased during the dry-wet season transition (Fig. 3), which is consistent with the development of new leaves, i.e., increased leaf area index (LAI), and increasing concentrations of nutrients in leaf that typically occurs when start wet season (Xiao et al. 2005, Biudes et al. 2014a, Asner and Martin 2008).

\section{GPP ESTIMATED WITH MODIS AND LANDSAT 5 TM}

The Gross Primary Production estimated by the Vegetation Photosynthesis Model (VPM) using EVI $\mathrm{I}_{\text {MODIS }}$ $\left(\mathrm{GPP}_{\text {EVI-MODIS }}\right)$ and the $\mathrm{NDVI}_{\mathrm{MODIS}}\left(\mathrm{GPP}_{\mathrm{NDVI}-\mathrm{MODIS}}\right)$, and Gross Primary Production estimated by the

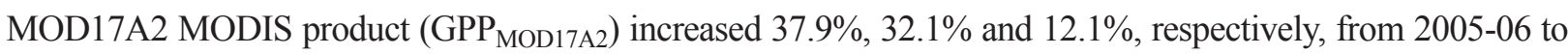
2007-08 (Fig. 4, Table II). They were underestimated by 3.5\%, 28.2\% and 36.4\%, respectively, compared to the Gross Primary Production measured by eddy covariance $\left(\mathrm{GPP}_{\mathrm{EC}}\right)$. The linear regression between the $\mathrm{GPP}_{\mathrm{EC}}$ and

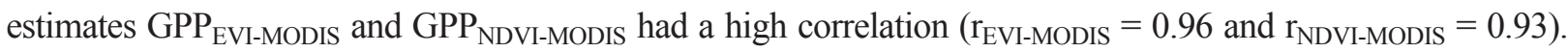

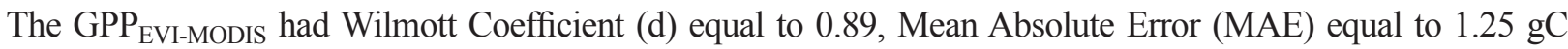
$\mathrm{m}^{-2}$ day $^{-1}$ and Root Mean Square Error (RMSE) equal to $1.48 \mathrm{gC} \mathrm{m}^{-2}$ day $^{-1}$ relative to $\mathrm{GPP}_{\mathrm{EC}}$ (Fig. 5a), while $\mathrm{GPP}_{\text {NDVI-MODIS }}$ had d equal to 0.64 , MAE equal to $2.30 \mathrm{gC} \mathrm{m}^{-2}$ day $^{-1}$ and RSME equal to $2.44 \mathrm{gC} \mathrm{m}^{-2}$ day $^{-1}$ (Fig. $5 b)$. The correlation and d between $\mathrm{GPP}_{\mathrm{MOD} 17 \mathrm{~A} 2}$ and $\mathrm{GPP}_{\mathrm{EC}}$ was lower than GPP $\mathrm{EVI}_{\text {MODIS }}$ and $\mathrm{GPP}_{\mathrm{NDVI}-\mathrm{MODIS}}$ $\left(\mathrm{r}_{\mathrm{MOD} 17 \mathrm{~A} 2}=0.67 ; \mathrm{d}=0.64\right)$, and had higher MAE $\left(2.93 \mathrm{gC} \mathrm{m}^{-2}\right.$ day $\left.^{-1}\right)$ and $\operatorname{RMSE}\left(3.21 \mathrm{gC} \mathrm{m}^{-2}\right.$ day $\left.^{-1}\right)$ (Fig. 5e). 


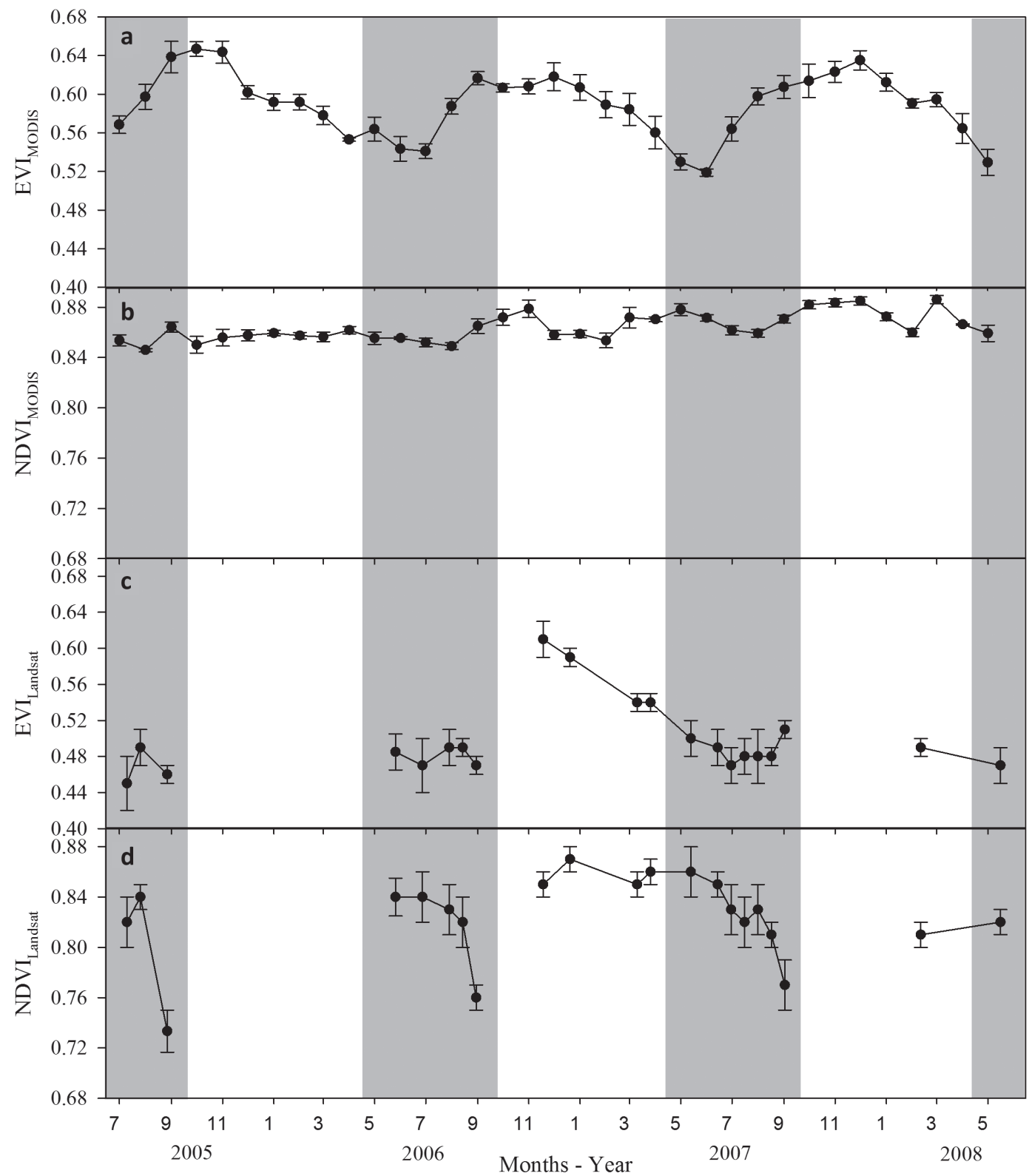

Fig. 3 - Monthly average of the Enhanced Vegetation Index (EVI) calculated form Moderate Resolution Imaging Spectroradiometer (MODIS) (a) and Landsat 5 TM (c) and Normalized Difference Vegetation Index (NDVI) calculated from MODIS (b) and Landsat 5 TM (d) in the Amazon-Cerrado transitional forest from July 2005 to June 2008. The gray vertical column represents the dry season.

The Gross Primary Production estimated by the Vegetation Photosynthesis Model (VPM) using $\mathrm{EVI}_{\text {Landsat }}\left(\mathrm{GPP}_{\mathrm{EVI} \text {-Landsat }}\right)$ and the $\mathrm{NDVI}_{\text {Landsat }}\left(\mathrm{GPP}_{\mathrm{NDVI} \text {-Landsat }}\right)$ agreed with the Gross Primary Production measured by eddy covariance $\left(\mathrm{GPP}_{\mathrm{EC}}\right)$ on both phase and magnitude. In general, $\mathrm{GPP}_{\mathrm{EVI}-\mathrm{Landsat}}$ was underestimated in $21.4 \%$, and $\mathrm{GPP}_{\mathrm{NDVI}-L a n d s a t}$ was overestimated in $31.1 \%$ compared to the $\mathrm{GPP}_{\mathrm{EC}}$. The GPP estimated by Landsat $5 \mathrm{TM}$ reflectance had high correlation $\left(\mathrm{r}_{\mathrm{EVI} \text {-Landsat }}=0.94\right.$ and $\mathrm{r}_{\mathrm{NDVI} \text {-Landsat }}=0.92$ ) with $\mathrm{GPP}_{\mathrm{EC}}$. The GPP $\mathrm{EVI}_{\text {-Landsat }}$ had d equal to 0.79 , MAE equal to $1.75 \mathrm{gC} \mathrm{m}^{-2}$ day $^{-1}$ and RMSE equal to 


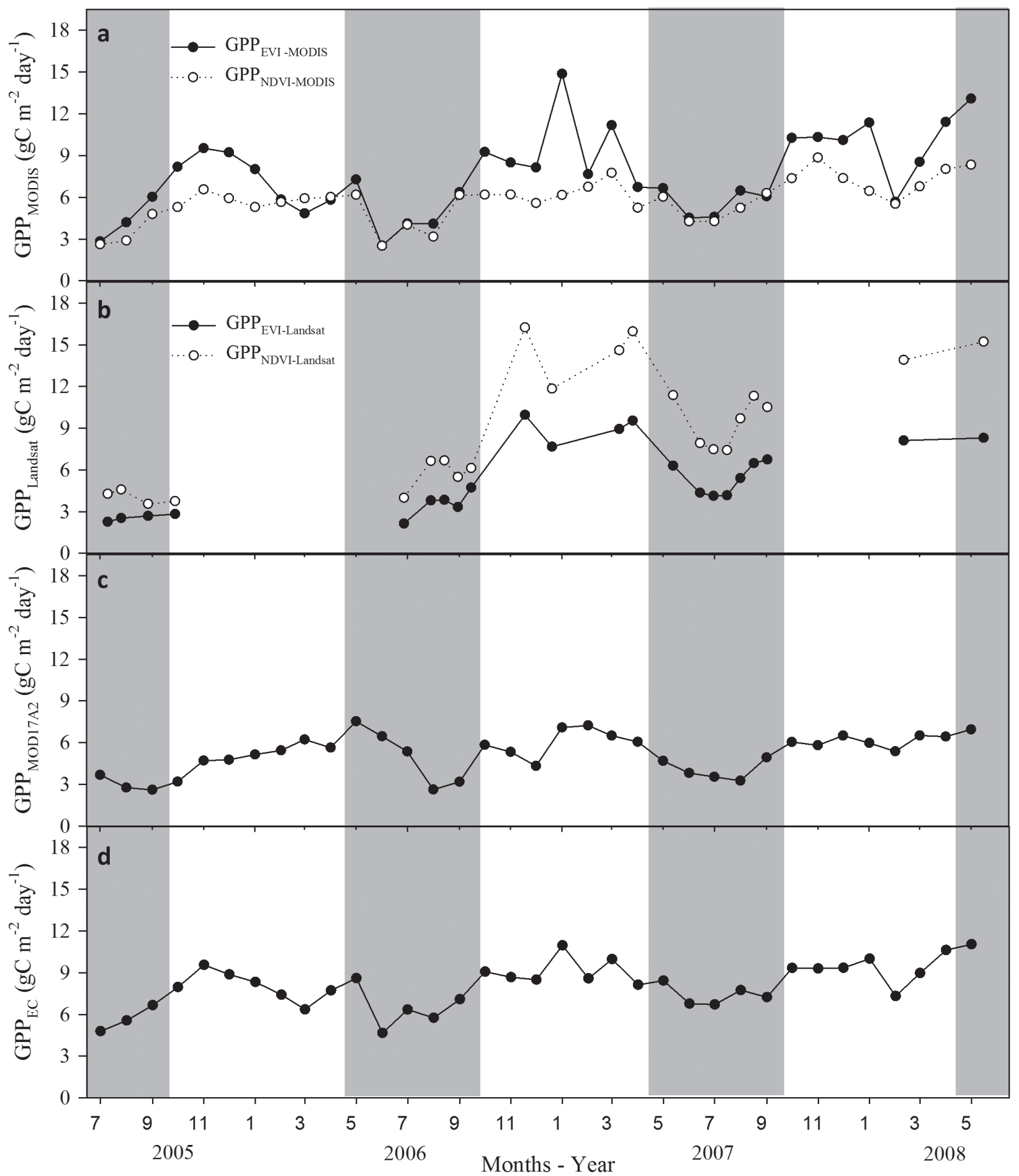

Fig. 4 - Monthly average of Gross Primary Production ( $\mathrm{gC} \mathrm{m}^{-2}$ day $\left.^{-1}\right)$ estimated from Vegetation Photosynthesis Model (VPM) using Enhanced Vegetation Index (EVI) and Normalized Difference Vegetation Index (NDVI) calculated from Moderate Resolution Imaging Spectroradiometer (MODIS) (a), using EVI and NDVI calculated from Landsat 5 TM (b), estimated by MOD17A2 MODIS GPP Product (c) and measured by eddy covariance (d) in the Amazon-Cerrado transitional forest from July 2005 to June 2008. The gray vertical column represents the dry season. 


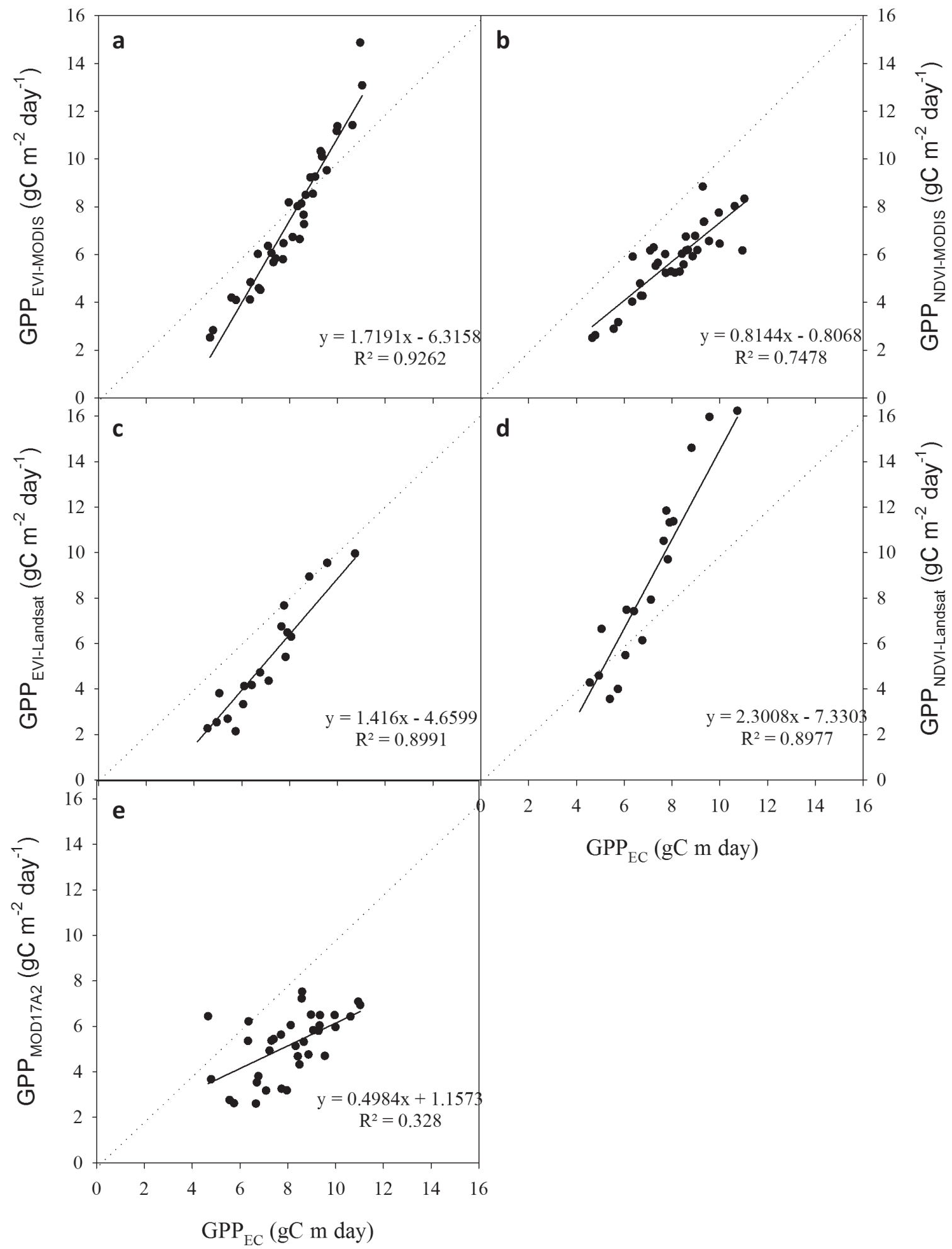

Fig. 5 - Relationship between Gross Primary Production (GPP) measured by eddy covariance and estimated from Vegetation Photosynthesis Model (VPM) using Enhanced Vegetation Index (EVI) (a) and Normalized Difference Vegetation Index (NDVI) (b) calculated from Moderate Resolution Imaging Spectroradiometer (MODIS), using EVI (c) and NDVI (d) calculated from Landsat 5 TM, and estimated by MOD17A2 MODIS GPP Product (e) in the Amazon-Cerrado transitional. 
$2.02 \mathrm{gC} \mathrm{m}^{-2}$ day $^{-1}$ (Fig. 5c) and the GPP $\mathrm{NDVI}_{\text {-MODIS }}$ had d equal to 0.74 , MAE equal to $2.41 \mathrm{gC} \mathrm{m}^{-2}$ day $^{-1}$ and RSME equal to $3.06 \mathrm{gC} \mathrm{m}^{-2}$ day $^{-1}$ in relation to $\operatorname{GPP}_{\mathrm{EC}}$ (Fig. 5d).

The maps of the GPP $\mathrm{EVI}_{\text {-Landsat }}$ and $\mathrm{GPP}_{\mathrm{NDVI}-L a n d s a t}$ with $30 \mathrm{~m}$ spatial resolution showed an increase in GPP from 2005-06 to 2007-2008, which was also observed in the histogram of Figures 6 and 8. The increase in GPP was studied by Vourlitis et al. (2011) and is due to the weather dynamic in the Amazon-Cerrado Transition Forest. Warm and dry during 2005-06, caused low GPP values, and wet and hot during 2006-07, and dry and cool during 2007-08 caused high GPP values (Vourlitis et al. 2011, Souza et al. 2014, Biudes et al. 2014b).

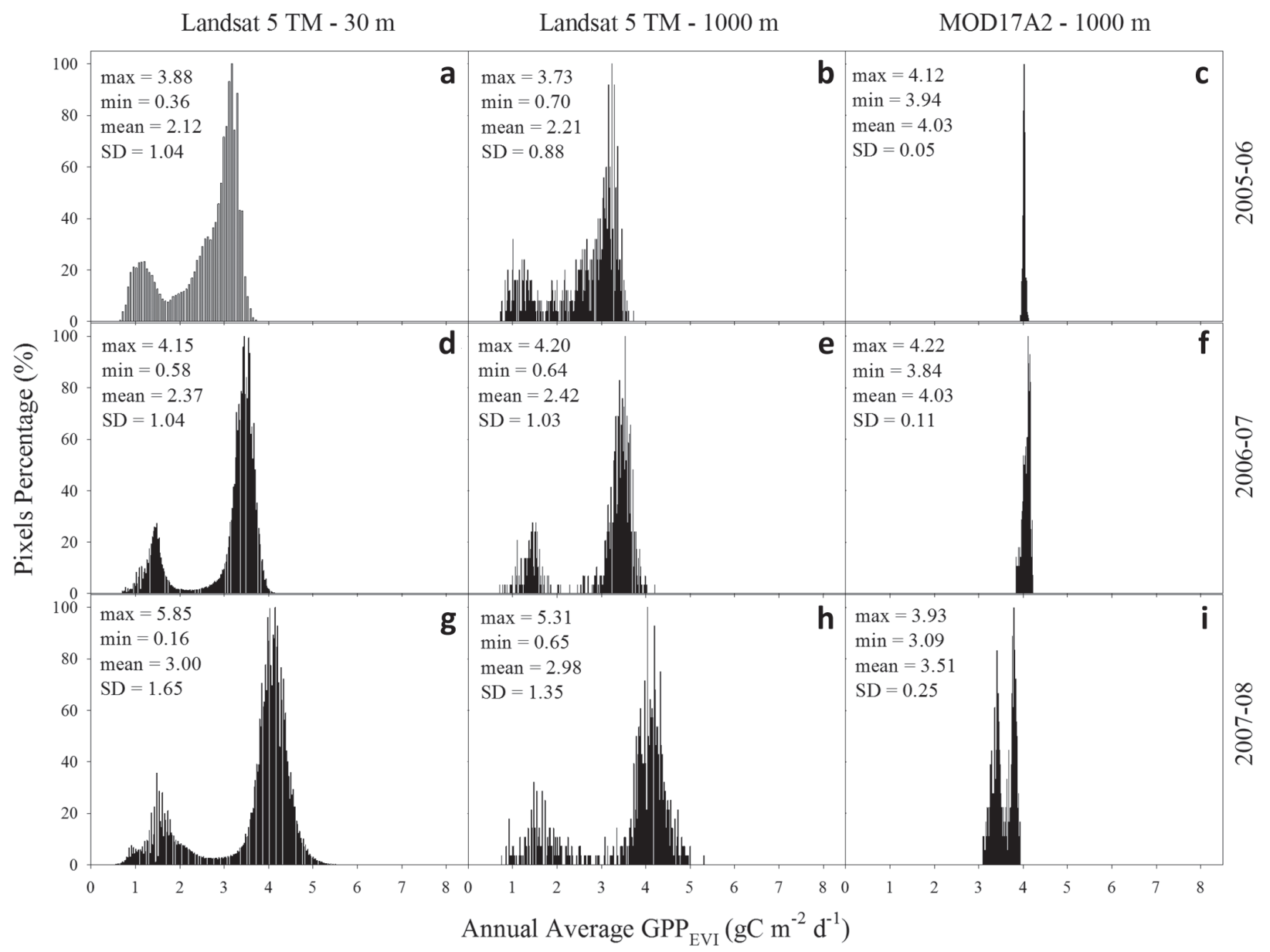

Fig. 6 - Histograms of maps of annual average GPP estimated from Vegetation Photosynthesis Model (VPM) using Enhanced Vegetation Index (EVI) from Landsat 5 TM with $30 \mathrm{~m}(\mathbf{a}, \mathbf{d}$ and $\mathbf{g})$ and $1000 \mathrm{~m}(\mathbf{b}, \mathbf{e}$ and $\mathbf{h})$ of spatial resolution and by MOD17A2 MODIS GPP Product (c, f, i) during 2005-06, 2006-07 and 2007-08, respectively.

The GPP maps estimated by VPM using Landsat 5 TM with $30 \mathrm{~m}$ spatial resolution were resampled to $1000 \mathrm{~m}$ in order to compare with the GPP estimated by the MOD17A2 GPP MODIS Product. The histograms of GPP maps estimated by VPM using Landsat 5 TM with $30 \mathrm{~m}$ and $1000 \mathrm{~m}$ spatial resolution relative to the GPP increasing along of the experiment were slightly different. The lower spatial resolution showed the highest amount of noise and gaps in the distribution of pixels. GPP EVI-Landsat $_{\text {with }} 30 \mathrm{~m}$ of spatial resolution increased $0,88 \mathrm{gC} \mathrm{m}^{2}$ day $^{-1}(41.5 \%)$ and with $1000 \mathrm{~m}$ of spatial resolution increased $0,77 \mathrm{gC} \mathrm{m}^{2}$ day $^{-1}(34.8 \%)$, while $\mathrm{GPP}_{\mathrm{NDVI} \text {-Landsat }}$ with $30 \mathrm{~m}$ of spatial resolution increased $1.37 \mathrm{gC} \mathrm{m}^{2}$ day $^{-1}(48.7 \%)$ 
and with $1000 \mathrm{~m}$ of spatial resolution increased $1.54 \mathrm{gC} \mathrm{m}^{2}$ day $^{-1}(60.1 \%)$ from 2005-06 to 2007-08. Unlike the GPP estimated from Landsat $5 \mathrm{TM}$, GPP $\mathrm{MOD} 17 \mathrm{~A} 2_{2}$ decreased $0.52 \mathrm{gC} \mathrm{m}^{2}$ day $^{-1}$ (12.9\%) from along the experiment (Fig. 7 and 9).

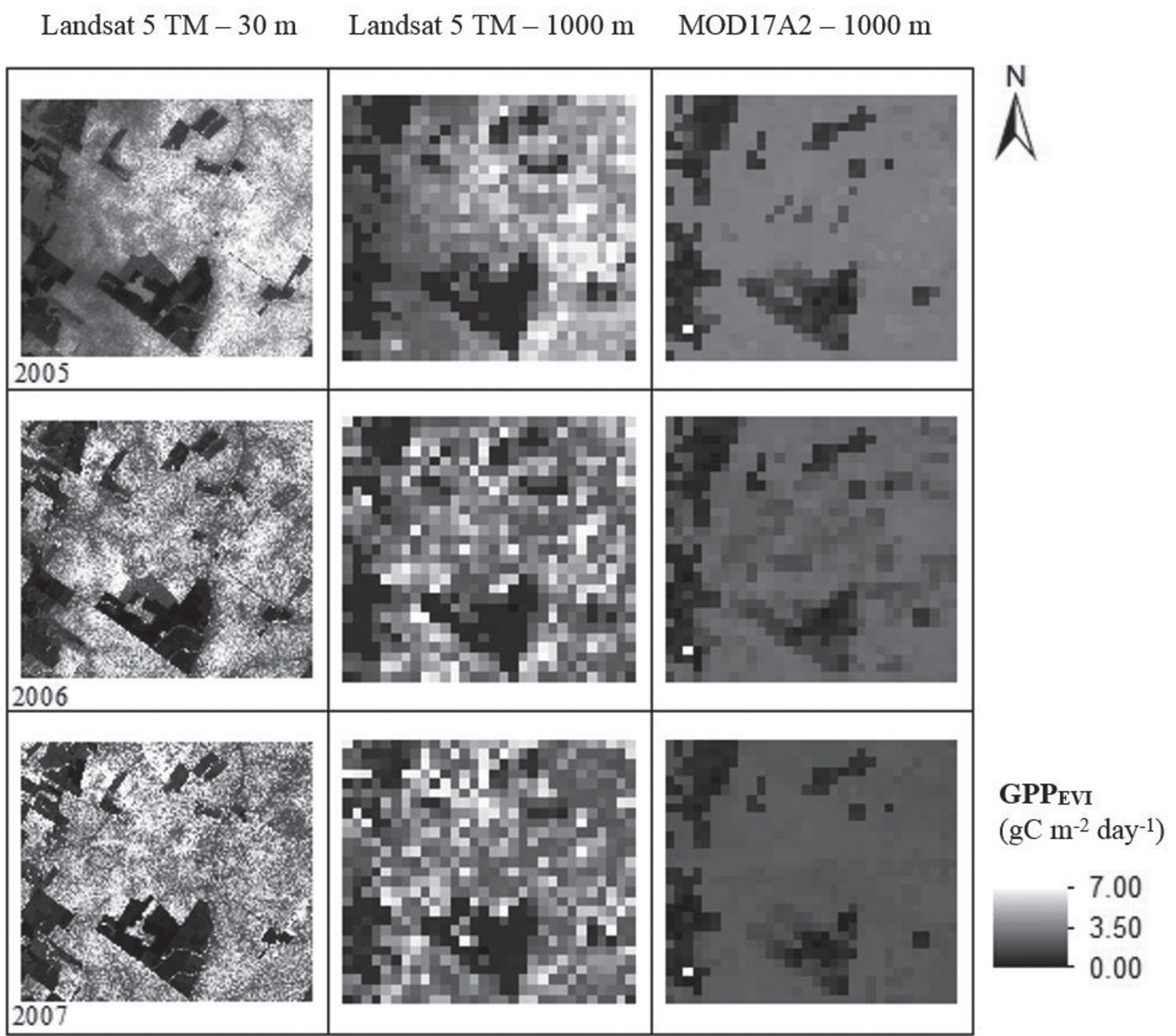

Fig. 7 - Maps of annual average GPP estimated from Vegetation Photosynthesis Model (VPM) using Enhanced Vegetation Index (EVI) from Landsat 5 TM with $30 \mathrm{~m}$ and $1000 \mathrm{~m}$ of spatial resolution and by MOD17A2 MODIS GPP Product.

The difference in the GPP $\mathrm{EVI}_{\mathrm{I}}$ and GPP $\mathrm{NDVI}_{\mathrm{N}}$ highlights the limits of each index. NDVI is more sensitive to the vegetation change and its mathematical formulation is based in the ratio of the difference in infrared and red reflectance and the sum infrared and red reflectance, while EVI is enhanced the NDVI, because its mathematical formulation not only uses infrared and red reflectance as well as the surface cover and soil effects (Jiang et al. 2008). EVI had higher correlation with leaf area index (LAI) than NDVI in the Amazon Forest and did not show saturation with high LAI $\left(>4 \mathrm{~m}^{2} \mathrm{~m}^{-2}\right)$ (Heute et al. 2006, Xiao et al. 2004).

The high agreement between GPP estimated using MODIS and measured in situ is well documented (Xiao et al. 2004, 2005, Li et al. 2007, Wang et al. 2010, Wu et al. 2010, Souza et al. 2014, Biudes et al. 2014b). The correlation, concordance and error metrics using Landsat 5 TM indexes were in the same order 


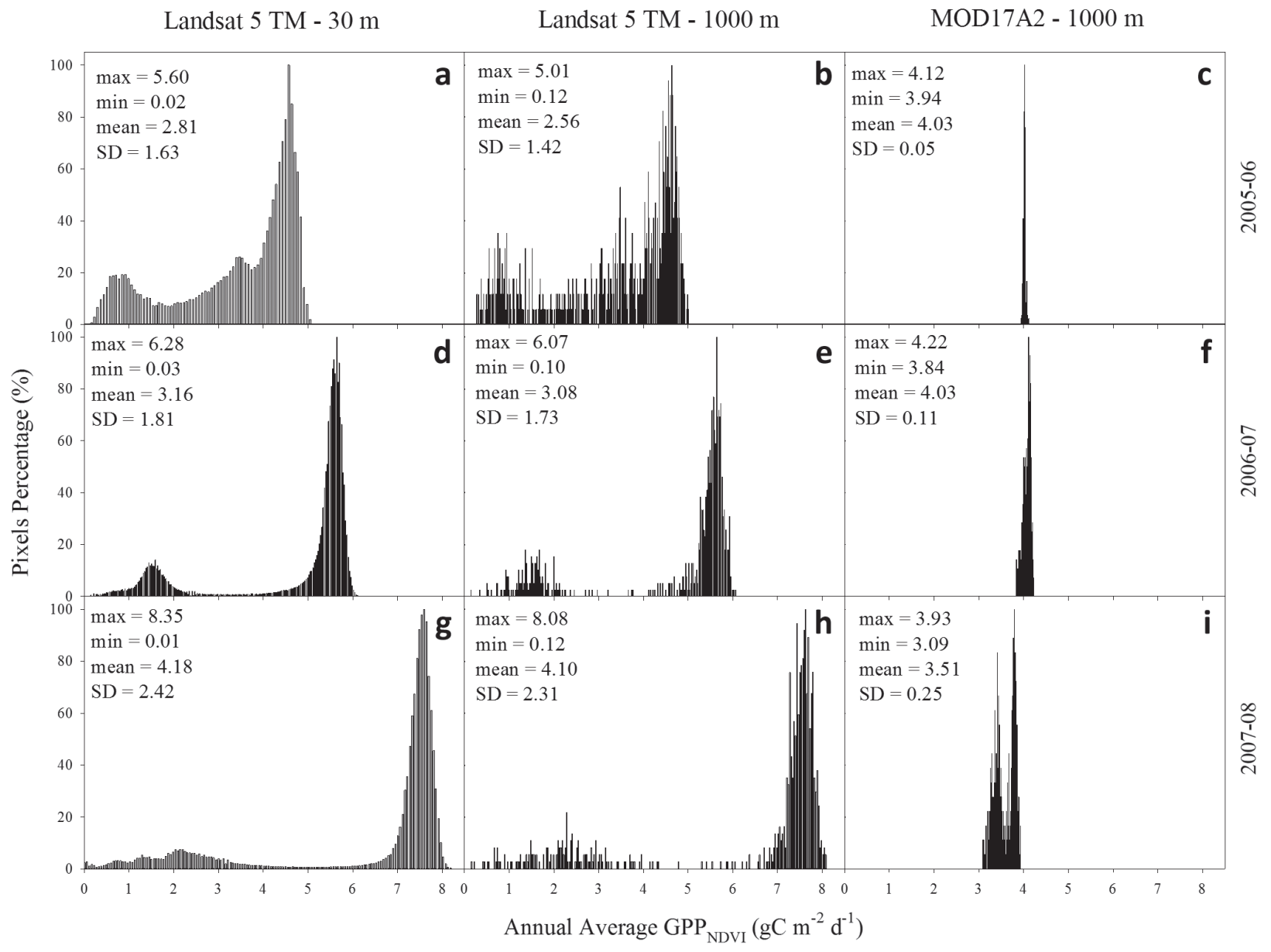

Fig. 8 - Histograms of maps of annual average GPP estimated from Vegetation Photosynthesis Model (VPM) using Normalized Difference Vegetation Index (NDVI) from Landsat 5 TM with $30 \mathrm{~m}(\mathbf{a}, \mathbf{d}$ and $\mathbf{g})$ and $1000 \mathrm{~m}(\mathbf{b}, \mathbf{e}$ and $\mathbf{h})$ of spatial resolution and by MOD17A2 MODIS GPP Product (c, f, i) during 2005-06, 2006-07 and 2007-08, respectively.

of magnitude of using MODIS indexes. The higher spatial resolution of surface reflectance provides more detailed information about the land surface, and hence, a better estimate of GPP (Wang and Liang 2009).

The low capacity of MOD17A2 GPP MODIS Product to estimate the spatial variation of GPP is due to its concept, which utilizes a similar concept of Vegetation Photosynthesis Model (VPM), but the maximum light use efficiency is obtained by a look-up-table based of the vegetation classification to calculate the GPP (Sims et al. 2006). In both model, the light use efficiency is a function of the climate variables and maximum light use efficiency, and the difference is in the climate input data. The VPM uses local climate data (Wu et al. 2010) and the MOD17A2 uses data produced by a global circulation model (Schubert et al. 1993).

\section{CONCLUSIONS}

The GPP estimated by MODIS and Landsat in the Amazon-Cerrado Transitional Forest between 2005 and 2008 showed similar dynamics both in phase and magnitude. The use of EVI provided higher correlation and Willmott's coefficient, and lower errors than NDVI to estimate the GPP of the Amazon-Cerrado Transitional Forest. 
Landsat $5 \mathrm{TM}-30 \mathrm{~m} \quad$ Landsat $5 \mathrm{TM}-1000 \mathrm{~m} \quad \mathrm{MOD} 17 \mathrm{~A} 2-1000 \mathrm{~m}$

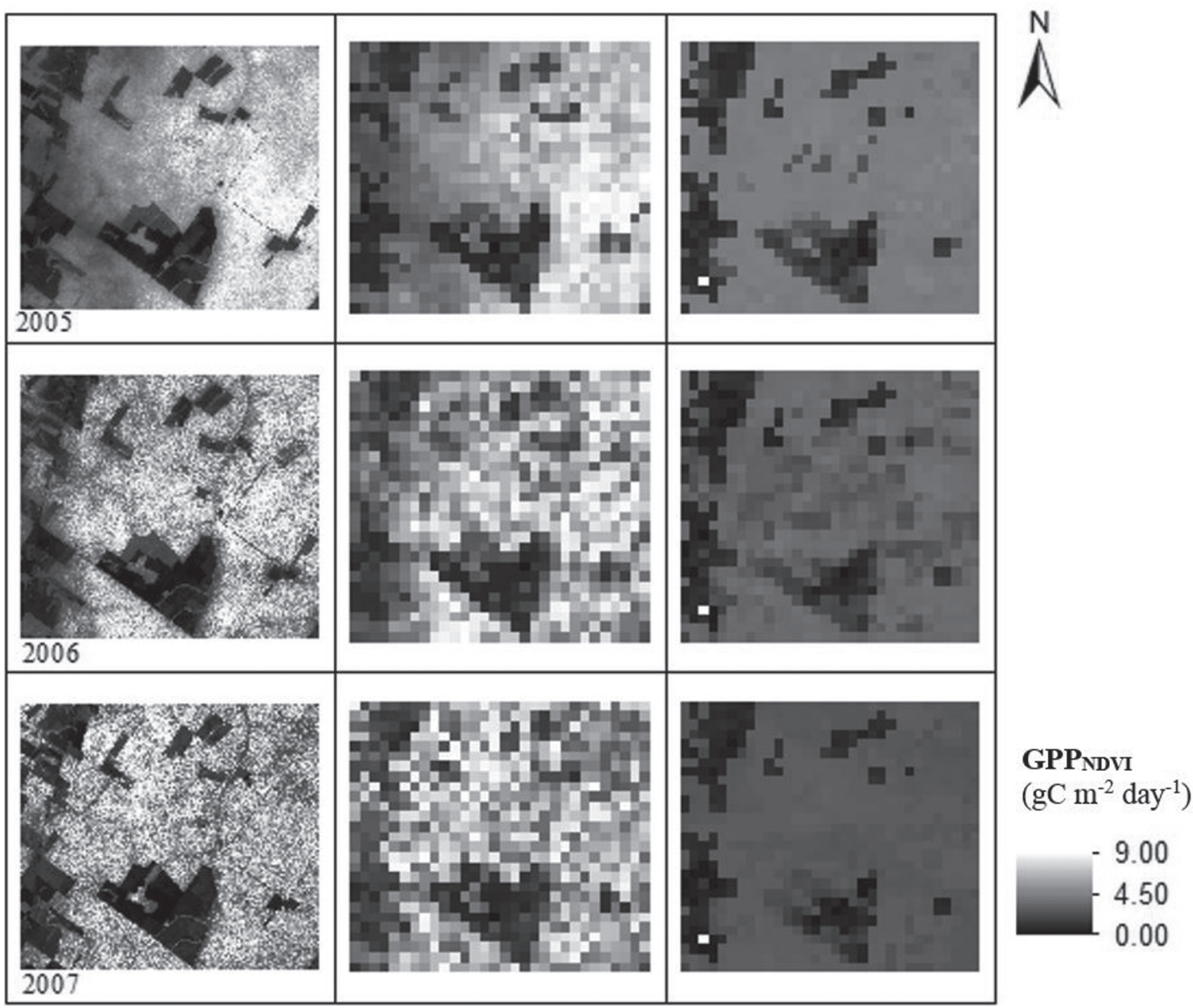

Fig. 9 - Maps of annual average GPP estimated from Vegetation Photosynthesis Model (VPM) using Normalized Difference Vegetation Index (NDVI) from Landsat 5 TM with $30 \mathrm{~m}$ and $1000 \mathrm{~m}$ of spatial resolution and by MOD17A2 MODIS GPP Product.

Our results highlight the opportunity to use both MODIS and Landsat 5 TM imagery to estimate the GPP in regional scale. The application of Landsat 5 TM provides better spatial resolution on regional GPP with more detailed spatial distribution, while MODIS can provide more GPP estimates due to its higher temporal resolution.

\section{ACKNOWLEDGMENTS}

The research was supported in part by the Universidade Federal de Mato Grosso (UFMT), Programa de Pós-Graduação em Física Ambiental (PPGFA) IF/UFMT, Coordenação de Aperfeiçoamento de Pessoal de Nível Superior (bolsistas CAPES Proc. no 9750/13-4 e 9768/13-0), Conselho Nacional de Desenvolvimento Científico e Tecnológico (MCT-CNPq-CT Infra-CT Energia nº 07/2006; Code: 620082/2006-2), Fundação de Amparo à Pesquisa do Estado de Mato Grosso (PRONEX/FAPEMAT - 2009 - Code: 823971/2009; Edital Universal/FAPEMAT 005/2012 - Proc. nº 331763/2012). 


\section{RESUMO}

A aceleração da atividade antropogênica aumentou a concentração de carbono na atmosfera, o que causa mudanças no clima regional. A produção primária bruta (GPP) é uma variável importante nos estudos do ciclo global de carbono, uma vez que define a taxa de extração de carbono da atmosfera pelos ecossistemas terrestres. O objetivo deste estudo foi estimar a GPP da Floresta de Transição Amazônia-Cerrado pelo modelo de fotossíntese da vegetação (VPM) utilizando dados meteorológicos locais e dados de sensoriamento remoto das refletâncias do MODIS e Landsat 5 TM entre 2005 e 2008. A GPP foi estimada pelo índice de Vegetação da Diferença Normalizada (NDVI) e pelo Índice de Vegetação Aprimorada (EVI) calculados com as imagens do MODIS e Landsat 5 TM. As GPP estimadas foram comparadas com medições em uma torre de fluxo de covariância de vórtices turbulentos. A GPP medida na torre foi consistente com os valores mais elevados durante a estação chuvosa e houve uma tendência de aumentar entre 2005 e 2008. A GPP estimada pelo VPM mostrou a mesma tendência de aumento observada nas GPP medidas e apresentou alta correlação e coeficiente de Willmott e baixas métricas de erro em comparação à GPP medida. Estes resultados indicaram alto potencial das imagens Landsat 5 TM para estimar a GPP da Floresta de Transição Amazônia-Cerrado pelo VPM.

Palavras-chave: Bacia Amazônica, Cerrado, ciclo do carbono, mudança climática, desmatamento, função do ecossistema.

\section{REFERENCES}

ACKerly DD, Thomas WW, Ferreira CAC AND PIRANi JR. 1989. The forest-cerrado transition zone in southern Amazonia: results of the 1985 Projecto Flora Amazonica Expedition to Mato Grosso. Brittonia 41: 113-128.

Allen R, IRMAK A, Trezza R, HENDrickX JMH, BASTIAANSSEN W AND KJAERSGAARD J. 2011. Satellite-based ET estimation in agriculture using SEBAL and METRIC. Hydrol Process 25: 4011-4027.

ASNER GP AND MARTIN RE. 2008. Spectral and chemical analysis of tropical forests: Scaling from leaf to canopy levels. Remote Sens Environ 112: 3958-3970.

ASRAR G, MYNENi RB AND CHOUdHuRY BJ. 1992. Spatial heterogeneity in vegetation canopies and remote sensing of absorbed photosynthetically active radiation: a modelling study. Remote Sens Environ 41: 85-103.

BASTIAANSSEN WGM AND ALI A. 2003. A new crop yield forecasting model based on satellite measurements applied across the Indus Basing, Pakistan. Agr Ecosyst Environ 94: 321-340.

Biudes MS, Machado NG, Danelichen VHM, Souza MC, Vourlitis GL and Nogueira JS. 2014a. Ground and Remote Sensing-Based Measurements of Leaf Area Index in a Transitional Forest and Seasonal Flooded Forest in Brazil. Int J Biometeorol 58(6): 1181-1193.

Biudes MS, SouZa MC, MACHAdo NG, DANELlichen VHM, Vourlitis GL AND NoGUEIRA JS. 2014b. Modelling gross primary production of a tropical semi-deciduous forest in the southern Amazon Basin. Int J Remote Sens 35(4): 1540-1562.

Costa MH, Biajoli MC, Sanches L, Malhado ACM, Hutyra LR, Da Rocha HR, Aguiar RG and De Araújo AC. 2010. Atmospheric versus vegetation controls of Amazonian tropical rain forest evapotranspiration: Are the wet and seasonally dry rain forests any different? J Geophys Res-Atmos 115: G04021.

Courault D, SGuin B And Olioso A. 2005. Review on estimation of evapotranspiration from remote sensing data: from empirical to numerical modeling approaches. Irrig Drain Systems 19: 223-249.

Da Rocha HR ET AL. 2009. Patterns of water and heat flux across a biome gradient from tropical forest to savanna in Brazil. J Geophys Res-Atmos 114: G00B12.

DAVIDSON EA ET AL. 2012. The Amazon basin in transition. Nature 481(7381): 321-328.

Fearnside P, Laurance WF, Cochrane MA, Bergen S, SAmpaio P, Barber C, D'Angelo S and Fernandes T. 2012. The future of Amazonia: models to predict the consequences of future infrastructure in Brazil's multi-annual plans. Novos Cadernos 15: 25-52.

FEARNSIDE PM. 2001. Soybean cultivation as a threat to the environment in Brazil. Environ Conserv 28: 23-38.

Fisher RA, Williams M, Da Costa AL, Malhi Y, Da Costa RF, Almeida S And Meir PW. 2007. The response of an Eastern Amazonian rainforest to drought stress: Results and modelling analyses from a through-fall exclusion experiment. Global Change Biol 13: 1-8.

GHIL M ET AL. 2002. Advanced Spectral Methods for Climatic Time Series. Rev Geophys 40: 1-41.

Godar J, Gardner TA, Tizado EJ And Pacheco P. 2014. Actor-specific contributions to the deforestation slowdown in the Brazilian Amazon. PNAS 11(43): 15591-15596. 
Golyandina N AND OsIPOVA E. 2007. The 'Caterpillar'- SSA Method for Analysis of Time Series with Missing Values. J Stat Plan Infer 137: 2642-2653.

HATFIELD JL, ASRAR G AND KANEMASU ET. 1984. Intercepted photosynthetically active radiation estimated by spectral reflectance. Rem Sens Environ 14: 65-75.

Hermance JF, Jacob RW, BRAdLey BA AND Mustard JF. 2007. Extracting Phenological Signals from Multiyear AVHRR NDVI Time Series: Framework for Applying High-Order Annual Splines. IEEE T Geosci Remote 45: 3264-3276.

HiRd JN AND MCDERMID GJ. 2009. Noise Reduction of NDVI Time Series: An Empirical Comparison of Selected Techniques. Rem Sens Environ 113: 248-258.

Huete AR, Didan K, Shimabukuro Ye, Ratana P, SAleska SR, Hutyra LR, Yang WZ, Nemani RR and Myneni R. 2006. Amazon rainforests green-up with sunlight in dry season. Geophys Res Lett 33: L06045.

HuETE AR, LIU HQ, BATChILY K AND VANLEEUWEN WA. 1997. Comparison of vegetation indices global set of TM images for EOSMODIS. Rem Sens Environ 59: 440-451.

INPE. 2013. Projeto PRODES: Monitoramento da floresta Amazônica Brasileira por satélite. Available at www.obt.inpe.br/prodes. Accessed on November 52014.

IPCC. 2014. Climate Change 2014: Impacts, Adaptation, and Vulnerability. Part A: Global and Sectoral Aspects. Contribution of Working Group II to the Fifth Assessment Report of the Intergovernmental Panel on Climate Change. In: Field CB et al. (Eds), Climate Change, Cambridge and New York: Cambridge University Press, Cambridge, United Kingdom and New York, NY, USA, p. 1132.

JENSEN JR. 2009. Sensoriamento remoto do ambiente: uma perspectiva em recursos terrestres. $2^{\text {a }}$ ed., São José dos Campos: Parêntese, $604 \mathrm{p}$.

JiANG Z, HUETE AR, DiDAN K AND MiURA T. 2008. Development of a two-band enhanced vegetation index without a blue band. Rem Sens Environ 112: 3833-3845.

Li Z, Yu G, XiAO X, Li Y, ZHAO X, REN C, ZHANG L AND FU Y. 2007. Modeling gross primary production of alpine ecosystems in the Tibetan Plateau using MODIS images and climate data. Rem Sens Environ 107: 510-519.

Machado LAT, LAURENT H, Dessay N AND MiRANDA I. 2004. Seasonal and diurnal variability of convection over the Amazonia: A comparison of different vegetation types and large scale forcing. Theor Appl Climatol 78: 61-77.

MALHI Y AND WRIGHT J. 2004. Spatial patterns and recent trends in the climate of tropical rainforest regions. Philos T R Soc B 359: 311-329.

NOAA - National Oceanic And Atmospheric Administration. Earth System Research Laboratory. 2014. Disponível em $<$ http://www.esrl.noaa.gov/gmd/ccgg/trends/global.html> Acessed on 01/08/2014.

PRIANTE-FILHO N ET AL. 2004. Comparison of the mass and energy exchange of a pasture and a mature transitional tropical forest of the southern Amazon Basin during a seasonal transition. Global Change Biol 10: 863-876.

Schubert SD, Rood RB And PFAendTner J. 1993. An assimilated dataset for earth science applications. B Am Meteorol Soc 74: 2331-2342.

Silva BB, Galvíncio JD, Montenegro SMGL, Machado CCC, Oliveira LMM AND Moura MSB. 2013. Determinação por sensoriamento remoto da produtividade primária bruta do perímetro irrigado São Gonçalo - PB. Rev Bras Meteorol 28(1): 57-64.

SIMS DA ET AL. 2006. On the use of MODIS EVI to assess gross primary productivity of North American ecosystems. J Geophys Res 111: G04015.

SouZa MC, Biudes MS, DANElichen VHM, Machado NG, DE Musis CR, Vourlitis GL AND NogueIRA JS. 2014. Estimation of gross primary production of the Amazon-Cerrado Transitional Forest by remote sensing techniques. Rev Bras Meteorol 29: 1-12.

Vourlitis GL, LOBO FA, BIUdES MS, ORTíz CER AND NOGUEIRA JS. 2011. Spatial variations in soil chemistry and organic matter content across a Vochysia divergens invasion front in the Brazilian Pantanal. Soil Sci Soc Am J 75: 1554-1561.

Vourlitis GL, NOGUEIRA JS, LOBO FA AND PINTO JUNIOR OB. 2015. Variations in evapotranspiration and climate for an Amazonian semi-deciduous forest over seasonal, annual, and El Niño cycles. Int J Biometeorol 59: 217-230.

Vourlitis GL, Nogueira JS, Lobo FA, SEndall KM, De FAria JLB, Dias CAA AND ANDrade NLR. 2008. Energy Balance and Canopy Conductance of a Tropical Semi-Deciduous Forest of the Southern Amazon Basin. Water Resour Res 44: W03412.

WANG K AND LiAng S. 2009. Evaluation of Aster and Modis land surface temperature and emissivity products using long-term surface longwave radiation observations at Surfrad sites. Rem Sens Environ 113: 1556-1565.

WANG Z, XIAO X AND YAN X. 2010. Modeling gross primary production of maize cropland and degraded grassland in northeastern China. Agr Forest Meteorol 150: 1160-1167.

WebB EK, PEARMAn GI AND LEUNING R. 1980. Corrections of flux measurements for density effects due water vapor transfer. Q J Roy Meteor Soc 106: 85-100.

WiLlmotT CJ AND MATSSURA K. 2005. Advantages of the mean absolute error (MAE) over the root mean square error (RMSE) in assessing average model performance. Clim Res 30: 79-92. 
Wohlfahrt G, Anfang C, Bahn M, Haslwanter A, Newesely C, Schmitt M, Drosler M, Pfadenhaeur J And Cernusca A. 2005. Quantifying nighttime ecosystem respiration of a meadow using eddy covariance, chambers and modeling. Agr Forest Meteorol 128: 141-162.

Wu C, MUNGER JW, NiU Z AND KUANG D. 2010. Comparison of multiple models for estimating gross primary production using MODIS and eddy covariance data in Harvard Forest. Rem Sens Environ 114: 2925-2939.

Xiao X, Zhang Q, Hollinger D, ABer J AND Moore III B. 2004. Modeling seasonal dynamics of gross primary production of an evergreen needleleaf forest using MODIS images and climate data. Ecol Appl 15: 954-969.

Xiao X, Zhang Q, Saleska S, Hutyra L, De Camargo P, Wofsy S, Frolking S, Boles S, Keller M and Moore B. 2005. Satellite-based Modeling of Gross Primary Production in a Seasonally Moist Tropical Evergreen Forest. Rem Sens Environ 94: 105-122. 